\title{
Bibliometrics cum grano Bibliometrija cum grano
}

\author{
Mirko PETRIĆ \\ Odjel za sociologiju, Sveučilište u Zadru / Department of Sociology, University of Zadar, Croatia \\ mpetric@unizd.hr
}

Although its title may suggest otherwise, the text that follows has not been written with a polemical intent. Instead, it should be understood as a somewhat longer footnote to the contribution published in the Forum section of the Revija za sociologiju, under the title "A Parochial Status of Croatian Sociology?" (Štulhofer, Baćak and Šuljok, 2010: 103-108).

Following a brief report on the performed bibliometric analysis, the authors claim that - according to their findings - Croatian sociology is situated at the margins of international productivity and visibility. At the end of their contribution, they propose measures that should be taken in order to change the situation in which - according to the authors - the discipline of sociology in Croatia "exist[s] on the margins of relevance, deliberately distanced from a rapidly globalizing world of social sciences" (Štulhofer, Baćak and Šuljok, 2010: 107).

I consider the text that I have just quoted from to be an inspiring contribution to the discussion of the topic it has brought to attention. I agree with its basic diagnosis (Croatian sociologists publish insufficiently in international publications), as well as with the suggested therapy (there should be incentives for outstanding research achievements, more
Unatoč tome što njegov naslov možda sugerira suprotno, tekst koji slijedi nije napisan s polemičkom namjerom. Umjesto toga, valja ga shvatiti kao nešto dulju fusnotu prilogu objavljenom u Forumu Revije za sociologiju, pod naslovom »Provincijalni karakter hrvatske sociologije?« (Štulhofer, Baćak i Šuljok, 2010: 103-108).

U tom su prilogu autori i autorica, nakon kraćeg izvještaja o obavljenoj bibliometrijskoj analizi, ustvrdili da se - prema njihovim nalazima - hrvatska sociologija nalazi na marginama međunarodne produktivnosti i vidljivosti. $\mathrm{Na}$ koncu, predložili su mjere potrebne da bi se promijenilo stanje u kojem - prema autorima i autorici - disciplina sociologije u Hrvatskoj »životar[i] na rubu znanstvene relevantnosti - svojevoljno distancirana od globaliziranog svijeta znanosti« (Štulhofer, Baćak i Šuljok, 2010: 107).

Upravo citirani tekst smatram poticajnim doprinosom raspravi na temu koju je otvorio. Slažem se s njegovom temeljnom dijagnozom (hrvatski sociolozi/ginje nedovoljno objavljuju u međunarodnim publikacijama), kao i s predloženom terapijom (nagrađivanje iznimnih znanstvenih postignuća, uvođenje zahtjevnijih uvjeta akademskog 
rigorous criteria of academic career advancement, and changes in the system of education of junior researchers).

However, in my opinion, the data put forward by the authors should by no means be taken for granted. Instead, they should be contextualized within a framework much wider than the one taken as relevant in the article under discussion. Likewise, although I do not dispute its final conclusions, I believe it is necessary to discuss the assumptions this and other similar inquiries depart from.

Why should this be done? At a most superficial level - that is, the one that intentionally stays within the limits of a quantitative, bibliometric imagination - one could perhaps say: because there exist seemingly equally authoritative data that contradict the assertion of complete marginality of Croatian sociology in international rankings.

For example, according to the calculation presented by the then president of the Austrian Sociological Association Christian Fleck at the 2009 conference of the Council of National Associations of International Sociological Association (ISA) in Taipei, Croatian sociology was ranked third in Europe based on the number of articles indexed in the Social Sciences $\mathrm{Ci}$ tation Index (SSCI) in the period between 1990 and 2008, in relation to the number of inhabitants (Fleck, 2010).

Had Fleck managed to apply yet another criterion, for which he was unable to find comparable data at the European level (human resources in science and technology as share of the labour force), Croatia's "ranking" in his calculation could have been even better. Similarly, there is no doubt that other criteria could be found, such as the number of published articles in relation to the absolute napredovanja te promjene $u$ načinu poduke znanstvenog podmlatka).

Međutim, smatram da podatke iznesene u prilogu nikako ne treba uzimati zdravo za gotovo, nego da ih je potrebno kontekstualizirati u okvir znatno širi od onoga koji se u napisu uzima za mjerodavan. Isto tako, iako ne osporavam njegov konačan zaključak, smatram potrebnim raspraviti pretpostavke s kojih je krenulo to i s kojih kreću druga slična istraživanja.

Zašto bi to trebalo učiniti? $\mathrm{Na}$ najpovršnijoj razini, odnosno onoj koja namjerno ostaje u granicama kvantitativne, bibliometrijske imaginacije, možda bi se moglo reći: zato što postoje i naizgled jednako mjerodavni podaci koji proturječe tvrdnji o potpunoj marginalnosti hrvatske sociologije u međunarodnim rangiranjima.

Primjerice, prema izračunu koji je na konferenciji Savjeta nacionalnih organizacija Međunarodnoga sociološkog društva (ISA) u Taipeiju 2009. iznio tadašnji predsjednik Austrijskoga sociološkog društva Christian Fleck (2010), hrvatska je sociologija u razdoblju između 1990. i 2008., po broju članaka referiranih u Social Sciences Citation Index (SSCI) u odnosu na broj stanovnika/ca zemlje, bila na trećem mjestu u Europi!

Da je u izračunu primijenjen još jedan kriterij za koji Fleck na europskoj razini nije našao usporedive podatke (ljudski resursi u znanosti i tehnologiji kao dio ukupne radne snage), "ranking" Hrvatske u ovom bi pogledu možda bio i još bolji. Također, nema sumnje da bi se mogle naći i druge osnove, poput apsolutnog iznosa BDPa ili stope izdvajanja za znanost u nje$\mathrm{mu}$, po kojima se - u odnosu na broj 
GDP figure or to science spending as a fraction of GDP, according to which the position of Croatian sociology in international rankings would certainly not be judged as totally marginal.

However, the question is again: why should this be done? Namely, the author of the quoted paper (Fleck, 2010), following his data analysis, calls into question the validity of SSCI and states that such a realization is troubling, given the prominence of this index in science policy.

What could be added as an unspoken conclusion to Fleck's paper is an estimate well-known to the sociological community, according to which there is no clear hierarchy of journals in that discipline, in contrast with some other branches and fields of science. As an additional support for that argument, related to the local context, one could mention that the Croatian Medical Journal, with its middling ranking in the field of medical journals, had a higher impact factor for the year 2009 than a number of world famous sociological journals. ${ }^{1}$

\footnotetext{
${ }^{1}$ According to the data found on the journal's web page (CMJ, 2010), the impact factor of the Croatian Medical Journal for the year 2009 was 1.373 , which ranked it as 62 nd among the 132 Current Contents journals in the category "Medicine, General and Internal". According to Jacobs (2010), in the field of sociology, only nine out of 106 journals listed in ISI Web of Knowledge for the same year had impact factors higher than 2.0. For example, British journals such as the British Journal of Sociology and Sociology, the highest ranked non-US sociological journals in Jacobs's comparative table, had impact factors of 1.473 and 1.464 . In this context, it is not uninteresting to mention that an "average article" published in one of the 114 journals in the field of sociology included in Thomson-Reuters's Science Citation In-
}

objavljenih članaka - položaj hrvatske sociologije u međunarodnim rangiranjima ne bi pokazivao kao potpuno marginalan.

Pitanje je, međutim, zašto bi se to činilo? Autor navedenog referata (Fleck, 2010), naime, nakon obavljene analize podataka dovodi u pitanje validnost SSCI-ja, te navodi da je takva spoznaja uznemirujuća, s obzirom na prominentnost tog indeksa $\mathrm{u}$ znanstvenim javnim politikama.

Kao neizrečen zaključak Fleckova priloga možda bi se mogla iznijeti sociološkoj zajednici dobro poznata procjena da u tom polju znanosti nema jasne hijerarhije važnosti časopisa, kao što je to slučaj u nekim drugim poljima i područjima. Kao dodatnu - lokalnoj publici blisku - potporu takvom stavu, moglo bi se, nadalje, spomenuti i to da je Croatian Medical Journal, kao osrednje rangirani medicinski časopis, $\mathrm{u}$ 2009. godini imao veći čimbenik utjecaja (impact factor) od niza svjetski poznatih socioloških časopisa. ${ }^{1}$

${ }^{1}$ Prema podacima istaknutim na mrežnoj stranici časopisa (CMJ, 2010), čimbenik utjecaja Croatian Medical Journala za 2009. godinu bio je 1,373, što ga je smjestilo na šezdeset $\mathrm{i}$ drugo od 132 mjesta u Current Contents kategoriji opće i interne medicine. Prema Jacobsu (2010), u polju sociologije $u$ istoj je godini čimbenik utjecaja veći od 2,0 imalo tek devet od 106 časopisa za koje je ovaj podatak postojao $\mathrm{u}$ bazi podataka ISI Web of Knowledge. Britanski časopisi British Journal of Sociology i Sociology, kao najbolje rangirani neamerički sociološki časopisi u Jacobsovu usporednom prikazu, imali su, primjerice, čimbenike utjecaja 1,473 i 1,464. U ovom kontekstu nije nezanimljivo spomenuti ni to da je "prosječan članak« objavljen u nekom od 114 časopisa u polju sociologije 
Finally, it could be said - together with Jacobs (2010) - that one of the problems with the current impact factor calculations is their annual rhythm. While it may be well suited to the natural sciences, this is certainly not the case for the social sciences, in which some articles only reach full visibility and impact after a decade or even more. (This, in turn, again according to Jacobs, means that the decisions on a sociologist's career advancement, based on impact factors, are at times made much earlier than the real impact of an article can be appropriately assessed.)

However, instead of such a discussion of the possible consequences of Fleck's conclusions, we should allow him to express his message in his own words. The final sentence of his text reads literally: "Sociology remains a discipline which is bounded by the nation state, and the discourses are limited by specialized subjects and national priorities" (Fleck, 2010: 17). To avoid any misunderstanding on what this means, one should remember that earlier in his article, the author clearly states: "Given the fragmentation not only of Europe's sociology but worldwide sociology, a comparison of impacts beyond the bor-

dex-Journal Citation Reports for the year 2009 had an impact factor of 3.702. At the same time, an "average article" published, for example, in one of the 132 journals in the field of immunology had an impact factor of 37.902, while an "average article" published in one of the 52 journals in the field of astronomy and astrophysics had an impact factor of 25.640. Among the social sciences, the highest impact factor can be found in the field of psychology defined as "multidisciplinary social science" (111 journals, impact factor 22.750) (AR, 2010).
Konačno, moglo bi se - zajedno s Jacobsom (2010) - navesti da je problem s aktualnim izračunima čimbenika utjecaja u tome što je njihov godišnji ritam prikladan prirodnim znanostima, ali ne i društvenima, u kojima neki članci do pune vidljivosti i utjecaja često dolaze čak i desetljeće i više nakon objavljivanja. (Ovo, pak, opet prema Jacobsu, znači da se odluke o nečijem znanstvenom napredovanju u polju sociologije, temeljene na čimbeniku utjecaja, katkad donose znatno prije nego što se stvarni utjecaj nekog članka može primjereno procijeniti.)

No, umjesto ovakvog razmatranja mogućih konzekvencija onoga što Fleck zaključuje u svom članku, dopustimo mu da sam kaže što ima reći. Posljednja rečenica njegove rasprave doslovno iznosi sljedeće: »Sociologija ostaje disciplinom omeđenom nacionalnim granicama, a diskursi su ograničeni specijaliziranim predmetima i nacionalnim prioritetima« (Fleck, 2010: 17). Da ne bi bilo nikakve zabune o tome što se ovim želi reći, nešto ranije u članku autor nedvosmisleno iznosi i sljedeće: »S obzirom na fragmentiranost ne samo europske sociologije, nego i svjetske sociologije, usporedba utjecaja ponad

uključenih u Thomson-Reutersov Science Citation Index - Journal Citation Reports za 2009. godinu imao čimbenik utjecaja od 3,702 , dok je primjerice "prosječan članak» objavljen u jednom od 132 časopisa u polju imunologije imao čimbenik utjecaja od 37,902 , a u jednom od 52 časopisa u polju astronomije i astrofizike 25,640. Od društvenih znanosti, na najveći čimbenik utjecaja nailazi se u polju psihologije definirane u smislu »multidisciplinarne društvene znanosti« (111 časopisa, čimbenik utjecaja 22,750) (AR, 2010). 
ders of particular national or discourse communities does not make much sense" (Fleck, 2010: 16).

There is not enough space here to recount all the examples and inferences made in Fleck's text. Nevertheless, it is hard to resist quoting at least some of Fleck's observations, indirectly connected with the topic of the Štulhofer, Baćak and Šuljok Forum contribution. For example, when it comes to citation indexing and impact factors, Fleck concludes from available data that Germany and neighbouring Switzerland and Austria have "closed their fences and seem to be satisfied communicating with, and citing, only those who speak the same language" (Fleck, 2010: 17). The same seems to be true for sociological texts written in Spanish and Portuguese, where a more intensive communication is evident with the sociological communities in South America than with those within the nominally shared European Research Area. Finally, it is interesting to note that the percentage of the sociological articles published in French corresponds roughly to the share of those within the EU 27 who speak French as their mother tongue, or that peer-reviewed journals are predominantly published in the English language.

However, what particularly drew my attention was Fleck's analytical transition from the language of the articles to the country in the affiliation of the author. Comparing "all articles" included in the Sociological Abstracts (SA) database with those published in peer-reviewed journals, Fleck concludes that over $90 \%$ of the articles published between 1990 and 2008 in Iceland, Estonia, Ireland, and Russia appeared in peer reviewed granica pojedine nacionalne ili zajednice diskursa nije odviše smislena« (Fleck, 2010: 16).

$\mathrm{Na}$ ovom mjestu nema dovoljno prostora za prepričavanje svih primjera i izvoda iz Fleckova teksta. Ipak, teško je odoljeti navođenju barem nekih Fleckovih zamjedbi, posredno povezanih $\mathrm{s}$ temom priloga u Forumu A. Štulhofera, V. Baćka i A. Šuljok. Ako je riječ o citiranosti i čimbeniku utjecaja, Fleck primjerice spominje da je iz dostupnih podataka vidljivo da su Njemačka i susjedne Švicarska i Austrija »zatvorile svoje granice i čine se zadovoljnim komuniciranjem sa, i citiranjem, samo onih koji govore istim jezikom « (Fleck, 2010: 17). Slično, čini se, vrijedi i za sociološke tekstove pisane na španjolskom i portugalskom, gdje je očita intenzivnija komunikacija sa sociološkim zajednicama u Južnoj Americi nego s onima s kojima se nominalno dijeli Europsko područje znanstvenog istraživanja (European Research Area). Zanimljivo je, konačno, primijetiti da postotak socioloških članaka objavljenih na francuskom približno odgovara udjelu onih koji u EU 27 govore francuski kao materinji jezik, kao i to da se časopisi koji radove objavljuju na temelju recenzija stručnjaka/inja u području (peer-reviewed journals) uglavnom objavljuju na engleskom jeziku.

No, ono što mi je osobito privuklo pozornost jest Fleckov analitički prijelaz s jezika članaka na zemlje s kojima su institucionalno povezani njihovi autori/ ce. Uspoređujući »sve članke«, dobivene putem baze podataka Sociological Abstracts (SA) s onima koji su objavljeni u časopisima s recenzijom stručnjaka/inja u području, Fleck zaključuje da se više od $90 \%$ članaka objavljenih od 1990. do 2008. godine na Islandu, u 
journals, while the ratio for Great Britain was $85 \%$, for Germany $67 \%$, France $62 \%$, Spain $58 \%$, and Italy $42 \%$. Fleck concedes that the validity of the employed data is disputable, but considers them to be meaningful indicators of the differing levels of conformity to the new rules of the game in the academic community.

In this regard, it is worthwhile passing along a piece of information that can be connected with the previously mentioned ranking of countries on the basis of the number of sociological articles referenced in the Social Sciences Citation Index (SSCI), in relation to the number of inhabitants. Fleck's analysis (2010: 14) shows that, apart from Great Britain, in the period between 1990 and 2008 only the following countries contributed more articles to the SSCI than to the older and less discriminative SA database: Russia, Croatia, Czech Republic, Slovakia, and Ukraine.

Fleck finds that the only sound explanation for this overrepresentation of the countries in question can be Institute for Scientific Information's attempt to reach out to the former Eastern Europe. According to him, certain journals from the countries in this region, claiming to use peer-review, were included in the SSCI database for reasons of regional representativeness. That this is indeed so is evidenced by a lack of indications that the number of submissions of articles from the mentioned countries to journals edited elsewhere has grown significantly.

One should say right away that such an explanation argues for the case of all those who have reacted sceptically to the mentioned overrepresentation of the Croatian authors in the Social Sci-
Estoniji, Irskoj i Rusiji odnosi na časopise s recenzijom stručnjaka/inja u području (peer-reviewed journals), dok za Veliku Britaniju taj postotak iznosi $85 \%$, Njemačku 67\%, Francusku 62\%, Španjolsku 58\% i Italiju 42\%. Fleck dopušta da je validnost podataka na kojima počiva ovakav izračun osporiva, no smatra da imaju smisla kao indikatori različitih stupnjeva retoričke konformnosti novim pravilima igre u akademskoj zajednici.

$\mathrm{U}$ ovom pogledu vrijedi prenijeti i zanimljiv podatak koji se može povezati s prethodno iznesenim rangiranjem prema broju članaka referiranih u Social Sciences Citation Index (SSCI) u odnosu na broj stanovnika/ca pojedine zemlje. Fleckova analiza (2010: 14) pokazuje da su, uz Veliku Britaniju, u razdoblju od 1990. do 2008. godine, više članaka referiranih u SSCI-ju od onih uvrštenih u stariju i manje diskriminativnu bazu podataka SA, imale samo Rusija, Hrvatska, Češka Republika, Slovačka i Ukrajina.

Jedino uvjerljivo objašnjenje takve prevelike zastupljenosti spomenutih zemalja Fleck nalazi u pokušaju otvaranja Institute for Scientific Information (ISI) nekadašnjoj Istočnoj Europi. Prema Flecku, pojedini časopisi iz ovih zemalja koji su ustvrdili da provode praksu recenziranja stručnjaka/inja u području (peer-review), najvjerojatnije su uključeni u bazu SSCI da bi se postigla stanovita regionalna reprezentativnost. Da je tome tako, pokazuje nedostatak indikatora da je znatno porastao broj članaka poslanih iz ovih zemalja u časopise koji se uređuju drugdje.

Ovakvo objašnjenje, valja odmah reći, daje za pravo svima koji su na prethodno spomenuti podatak o natprosječnoj zastupljenosti hrvatskih autora/ ica u Social Sciences Citation Index 
ences Citation Index (SSCI). The sceptics have asserted that it should be attributed exclusively to the fact that a journal edited in Croatia had been admitted to SSCI. According to such views, a result achieved on the basis of such admittance of a journal to SSCI is not "realistic" and does not have "real" value.

However, faced with such an assertion, and being familiar with the conditions of other recent admittances to the mentioned database, one should ask: what is "realistic" in the whole process and what does have "real" value?

According to Fleck (2010: 15) - let us return to his sober inferences - ISI's data for the year 2007 encompass 96 sociological journals, out of which 44 are from Europe. The latter, however, include a number of journals which would be considered as American by their readership, or at least as "neither European nor American". It is a matter of curiosity that the list of nominally "European" journals also includes the Journal of Sociology, which is edited by the Australian Sociological Association, but its publisher is located in Great Britain.

"In reality", says Fleck, nearly every other "European" journal should be excluded from the list as not representing "Europe". Added to this estimate should be the fact that the publishers of no less than 23 out of the mentioned 44 journals are located in Great Britain and six in the Netherlands, which indicates high levels of concentration in academic publishing. Germany was represented on the list by four, France by three, and the remaining eight European countries with only one journal each.

But that is not all: Fleck goes on to say that only nine out of 27 European
(SSCI) u odnosu na broj stanovnika/ca zemlje, reagirali sa skepsom i ustvrdili da je to isključivo stoga što je u SSCI pripušten časopis koji se uređuje $u$ Hrvatskoj. Prema takvim reakcijama, rezultat postignut temeljem ovakvog uvrštenja časopisa u SSCI nije »realan« i nema "pravu« vrijednost.

U susretu s ovakvom tvrdnjom, a poznajući prakse povezane s drugim recentnim uvrštenjima na spominjani indeks, potrebno se međutim zapitati: što je u svemu »realno« i što ima »pravu« vrijednost?

Prema Flecku (2010: 15) - vratimo se opet njegovim trijeznim izvodima ISI-jevi podaci za 2007. godinu obuhvaćali su 96 socioloških časopisa, od čega 44 iz Europe. Potonji, međutim, obuhvaćaju i niz časopisa koje bi većina njihova čitateljstva smatrala američkim, ili u najmanju ruku »ni europskim ni američkim«. Kuriozitet je da popis nominalno »europskih« časopisa uključuje i Journal of Sociology, koji uređuje Australsko sociološko društvo, ali mu je sjedište izdavača u Velikoj Britaniji.

»U stvarnosti«, kaže Fleck, gotovo svaki drugi »europski« časopis s tog popisa trebalo bi isključiti kao nešto što ne predstavlja »Europu«. Toj bi procjeni trebalo dodati i podatak da su izdavači ni manje ni više nego 23 od spominjana 44 časopisa smješteni u Velikoj Britaniji, dok ih šest ima sjedište u Nizozemskoj, što upućuje na stupanj uznapredovalosti procesa koncentracije $\mathrm{u}$ akademskom nakladništvu. Njemačka je u popisu sudjelovala s četiri a Francuska s tri časopisa, dok je preostalih osam u njega uključenih europskih zemalja bilo zastupljeno samo s po jednim časopisom.

No, to nije sve: Fleck nadalje navodi $\mathrm{i}$ to da je $\mathrm{u}$ popis SSCI-ja bilo 
member states were listed in SSCI, as well as only 11 out of 43 countries eligible for European research money. In other words, "[m]ore than half of Europe is not covered by SSCI, even though sociology exists in all of these countries" (Fleck, 2010: 15).

Trying to answer why, Fleck offers but a speculation: he hypothesizes that all of this is so because the Thomson Corporation (which acquired ISI already in 1992, and has recently merged with Reuters into an even bigger global seller of information), sees the countries in the former Eastern Europe and in what was once the Soviet Union as more promising markets for its services than Turkey, Greece, Portugal, Spain, Italy, Finland and so on.

Having said all this, two questions should be posed. The first one is of pragmatic nature and with a slightly cynical intonation. It could be formulated like this: if a corporation that owns the database adapts it to meet the needs of its market expansion, why should not academics that provide articles for it use the fact of being referenced on their small academic markets? That approach - which I do not advocate, but which has a certain justification - departs from the premise according to which a "CC article is a CC article" and argues that those who set the number of Current Contents publications as a criterion for academic advancement should not split hairs any further. $^{2}$

\footnotetext{
${ }^{2}$ To the sorrow of those who advocate this approach, the politics of not splitting hairs is not tenable in the long run, if for nothing else than because the notion of "impact factor" is irrepressibly penetrating the field of social sciences. According to Fleck, "[e]ven those parts of the social sciences and humanities which still resist the use of simple
}

uključeno samo devet od 27 članica Europske unije te samo 11 od 43 zemlje koje u različitim oblicima mogu aspirirati na novac koji EU izdvaja za znanost. Drugim riječima, »[v]iše od pola Europe nije pokriveno SSCI-jem, premda sociologija postoji u svim tim zemljama« (Fleck, 2010: 15).

U odgovoru na pitanje "zašto«, Fleck nudi tek spekulaciju: pretpostavlja da je tako stoga što tvrtka Thomson (koja je kupila ISI još 1992., a odnedavna je s Reutersom udružena $u$ još većega globalnog prodavatelja informacija), vidi zemlje u bivšoj Istočnoj Europi i zemljama nekadašnjega Sovjetskog Saveza kao tržišta na kojima ima veću priliku prodati svoje usluge nego u Turskoj, Grčkoj, Portugalu, Španjolskoj, Italiji, Finskoj i drugdje.

Kad je sve ovo izrečeno, postavljaju nam se dva pitanja. Prvo je pragmatične naravi i pomalo je cinično intonirano. Moglo bi ga se formulirati na sljedeći način: ako tvrtka koja posjeduje predmetni indeks taj indeks prilagođava vlastitim tržišnim potrebama, zašto znanstvenici/e, od čijih se članaka indeks sastoji, ne bi njegove rezultate koristili na vlastitom, malom akademskom tržištu, u svrhu znanstvenog napredovanja? U toj logici, koju ne zagovaram, ali koja ima stanovito utemeljenje, polazi se od toga da je »CC članak CC članak« i da oni koji kriterij ove vrste publiciranosti (Current Contents) postavljaju kao kriterij znanstvenog napredovanja ne bi trebali dodatno cjepidlačiti ni u kojem pogledu. ${ }^{2}$ ${ }^{2} \mathrm{Na}$ žalost onih koji zagovaraju ovakav
pristup, politika »necjepidlačenja« nije
dugoročno održiva, već i stoga što »čim-
benik utjecaja« (impact factor) nezadrživo
prodire i u društvene znanosti te će se -
kao što kaže Fleck - »[č]ak i oni dijelovi 
The second question that should be posed following quoted Fleck's argumentation is much more important. It asks: what has actually been achieved by exposing the selected population of Croatian sociologists to an intentionally "strong and restrictive test" (Štulhofer, Baćak and Šuljok, 2010: 104) of international publications and citations, whose results were put forward in the Forum section of the Revija za sociologiju?

Leaving aside objections that could perhaps be made to the criteria on the basis of which it was performed, ${ }^{3}$ one

numbers as an indicator of the impact factor will probably soon surrender" (Fleck, 2010: 16). In the context of his contribution, Fleck was of the opinion that one should not enter into a debate on whether such indicators are valid, if for nothing else than because rankings derived from them create a reality of their own, which should be accounted for in some way. On the other hand, in the future it will be simply necessary to at least try to explain the insufficient robustness of instruments and insufficient reliability of citation data in certain fields. This, among other things, is evidenced by the intention of the British government to introduce until now only experimentally applied bibliometric criteria in the next research assessment of higher education institutions in the country (scheduled for the year 2014, under the title Research Excellence Framework REF) (HEFCE, 2010).

${ }^{3}$ For example, bearing in mind the situation in the institutions more intensively participating in international research, one could ask why the Štulhofer, Baćak and Šljok inquiry takes into account only the productivity of academically most senior sociologists? Why does it refer only to the research results of full and associate professors, as well as of institute researchers of the same rank? Namely, it is well known that young researchers usually invest a spe-
Drugo, znatno važnije pitanje, koje valja postaviti nakon gore navođenih Fleckovih izvoda jest: što se zapravo postiglo izlaganjem odabrane populacije hrvatskih sociologa/inja namjerno »snaž[nom] i restriktiv[nom] test[u]« (Štulhofer, Baćak i Šuljok, 2010: 104) međunarodne publiciranosti i citiranosti, čiji su rezultati izneseni u Forumu Revije za sociologiju?

Ostavljajući po strani prigovore koji bi se možda mogli uputiti kriterijima na temelju kojih je ono provedeno, ${ }^{3}$

humanističkih i društvenih znanosti koji se još uvijek opiru upotrebi jednostavnih brojeva kao indikatora čimbenika utjecaja, vjerojatno uskoro predati« (Fleck, 2010: 16). U kontekstu svog priloga, Fleck je smatrao da se ne treba upuštati u raspravu o tome koliko su takvi indikatori validni, već i stoga što rangiranja temeljena na njima neizbježno stvaraju vlastitu stvarnost, koju na neki način valja uzeti u obzir. S druge strane, u budućnosti će očito biti nužno pokušati objasniti nedovoljnu robusnost instrumenata $\mathrm{i}$ pouzdanost podataka o citiranosti tekstova u pojedinim područjima. O tome svjedoči i namjera britanske Vlade da u sljedeću provjeru znanstvene izvrsnosti visokoškolskih ustanova u zemlji (predviđena za 2014., pod nazivom Research Excellence Framework - REF) uvede bibliometrijske kriterije koji su dosad tek pokusno korišteni (HEFCE, 2010).

3 U usporedbi sa stanjem kakvo vlada na ustanovama intenzivnije uključenima u međunarodnu znanstvenu proizvodnju, moglo bi se, primjerice, priupitati zašto su u istraživanju Štulhofera, Baćka i Šuljok u obzir uzimani samo rezultati sociologa/inja u najvišim znanstvenim zvanjima (redoviti i izvanredni profesori/ce te istraživači/ce istog ranga)? Poznato je, naime, da u međunarodnu publiciranost osobite napore drugdje ulažu upravo mlađi istraživači/ce, kojima je cilj postići viša zvanja 
could say that the performed mini inquiry has yielded results which make it possible to start a discussion (but not more than that!) of the topic that the quoted Forum contribution took as its subject.

Based on the criteria of the inquiry performed by Štulhofer, Baćak and Šuljok, one can indeed conclude that international publications and citation impacts of the senior Croatian sociologists are modest. Furthermore, one can also conclude that those Croatian sociologists employed at the Faculty of Humanities and Social Sciences in Zagreb publish less internationally and are less quoted than their counterparts employed at the two higher education institutions in Ljubljana offering study programs in sociology. ${ }^{4}$

cial effort into international publications, in order to achieve academic seniority and a more permanent place in the university system. (After all, for the most senior researchers, there also exist other success criteria, such as leadership of research programs and projects or even the absolute sum of funds won for their implementation). Furthermore, it is not clear why the Faculty of Humanities and Social Sciences in Zagreb was chosen for comparison with Slovenian institutions as an institution with a doctoral program in sociology, when in actuality this program includes a number of academics from other institutions of higher education and research institutes in Croatia. And finally, the interfaculty comparison with the productivity of psychology professors can hardly be relevant given considerably different citation standards in that field (see footnote 1).

${ }^{4}$ Speaking of the situation at the Faculty of Arts in Ljubljana, one should say that the fact that two out of eight sociology professors employed there have published in international journals referenced in the Scopus database in the examined period is not particularly impressive, even bearing in mind the really discouraging Zagreb ratio of 1:12. moglo bi se reći da je to miniistraživanje dalo rezultate koji omogućuju početak razgovora (ali ne više od toga!) o temi koje se navedeni prilog u Forumu poduhvatio.

$\mathrm{Na}$ temelju istraživanja provedenoga prema kriterijima koje su postavili Štulhofer, Baćak i Šuljok, može se doista zaključiti da su međunarodna publiciranost i citatni utjecaj sociologa/inja u najvišim zvanjima $u$ Hrvatskoj skromni te da - barem na Odsjeku za sociologiju Filozofskog fakulteta u Zagrebu - oni znatno manje međunarodno objavljuju i znatno su manje citirani od svojih kolega/ica na dvjema visokoškolskim ustanovama na kojima se podučava sociologija $u$ Ljubljani. ${ }^{4}$

i smjestiti se trajnije u sveučilišni sustav. (Za znanstvenike/ce najvišeg ranga, postoje, uostalom, i drugi kriteriji, poput vođenja međunarodnih znanstvenih programa $i$ projekata ili čak iznosa sredstava osiguranih za njihovo provođenje.) Nadalje, nije jasno zašto je - za usporedbu sa stanjem u Sloveniji - Filozofski fakultet u Zagrebu odabran kao ustanova koja ima doktorski program iz sociologije, kad u tom programu sudjeluje i cijeli niz znanstvenika/ca s drugih visokoškolskih ustanova i instituta u Hrvatskoj. Konačno, unutarfakultetska usporedba sa stanjem među profesorima/ cama psihologije teško da može biti relevantna s obzirom na znatno drukčije standarde citiranosti u tom polju (v. fusnotu 1).

${ }^{4} \mathrm{Kad}$ je riječ o stanju na Filozofskom fakultetu u Ljubljani, valja reći da ni podatak da dvoje od osam profesora/ica sociologije koji su u promatranome razdoblju objavili radove u međunarodnim časopisima referiranim u bazi Scopus nije osobito impresivan, čak ni u odnosu na doista destimulativan zagrebački omjer od jedan naprama dvanaest. 
One cannot deny that the Štulhofer, Baćak and Šuljok Forum contribution is in a sense revealing, but it should be said that it also hides a lot from view. What exactly? To begin with, everything discussed in Fleck's (2010) and Jacobs's (2010) contributions, the content of which has been relatively extensively reported on in this text.

What should be said now is that both these contributions are enclosed in a relatively narrow intraprofessional sociological debate. The topic of academic imperialism is only implicitly touched upon in the quoted texts, concentrated predominantly on bibliometric elements. There is no doubt that it deserves to be discussed in detail. However, for the sake of completeness, it is now necessary to introduce the topic of the social responsibility of sociology.

The debate can be entered starting from Giddens's notion of "double hermeneutic", Bauman's vision of the sociologist as "interpreter", or the idea of "public sociology" recently especially insisted on by the current president of the International Sociological Association (ISA) Michael Burawoy. Whatever path of entry we choose, it is hard not to notice the topicality of the need for the increased social engagement of the discipline. At the same time, one should also remember that such engagement was already present in the discipline at its outset.

The question today is, however, how to achieve the much needed connection with the local circumstances. In other words, how to achieve the responsibility of the discipline to the local community, in the conditions of an ever more globalized research system whose success criteria are frequently remote from local needs?

The dilemma faced by the sociologists from the societies and cultures whose
Ne može se poreći da prilog u Forumu Štulhofera, Baćka i Šuljok nešto otkriva, ali također valja reći i to da mnogo toga skriva. Što točno? Za početak, sve ono o čemu se raspravlja u prilozima Flecka (2010) i Jacobsa (2010), čiji je sadržaj razmjerno opsežno prenesen u prvom dijelu ovoga teksta.

Ovdje valja napomenuti $\mathrm{i}$ to da su oba spomenuta priloga još uvijek zatvorena u razmjerno uska unutarstrukovna sociološka razmatranja. Problematika akademskog imperijalizma tek se marginalno ocrtava u tim tekstovima usredotočenim pretežno na bibliometrijske elemente. Nema sumnje da to zaslužuje podrobniju raspravu. Međutim, radi potpunosti, sada je potrebno uvesti i problematiku društvene odgovornosti sociologije.

Bilo da se u tu raspravu uđe polazeći od Giddensova pojma »dvostruke hermeneutike«, Baumanove vizije sociologa/inje kao »interpretatora/ice«, ili pak zamisli »javne sociologije«, na kojoj posljednjih godina osobito inzistira aktualni predsjednik Međunarodnoga sociološkog društva (ISA) Michael Burawoy, neosporna je aktualnost potrebe pojačanog društvenog angažmana discipline, koji je uostalom ionako već u njezinim korijenima.

Pitanje je, međutim, kako danas postići potrebnu društvenu povezanost $\mathrm{s}$ lokalnim okolnostima. Drugim riječima, kako postići odgovornost discipline prema lokalnoj zajednici, u uvjetima sve globaliziranijega znanstvenog pogona čiji su kriteriji uspješnosti često daleko od lokalnih potreba?

Dvojbu pred kojom se u ovom pogledu nalaze sociolozi/ginje iz društava i kultura čiji »lokalni« problemi 
"local" problems are not considered to be "global" at the same time, has been graphically expressed by Sari Hanafi, Associate Professor at the American University in Beirut. In the titles of some of his recent lectures and publications (Hanafi, 2010, 2011) he plays with the well known slogan "publish or perish".

According to Hanafi, the situation of researchers in the geographical area he refers to as the "Arab East" (encompassing Egypt, Syria, the Palestinian territory, Jordan, and Lebanon) can be described by means of a direct opposition between two contrasting options: "publish globally and perish locally" or "publish locally and perish globally".

The dilemma is applicable to the situations of researchers in the countries in a roughly similar position. However, it should be stressed that it does not concern only the possible personal choices of those researchers who are in position to publish internationally. As revealed by Hanafi's discussions, the point at issue is the process that can seriously decapacitate local research for dealing with problems that need to be solved by the local community. This process comes about as a result of insisting on institutional isomorphism with the "global players" (which are, in Hanafi's examples, of American origin).

Hanafi (2010: 5) claims that the idea of an effectively proclaimed "simple internationalization" springs from a modernist imperative of producing "objective" knowledge. Such an approach neglects the situated questions ("for whom, for what, for when, for where" and "from whose viewpoint"). Consequently, it privileges theoretical and statistical analysis and leads to the demise of fieldwork and textual analysis.

Needless to say, Hanafi's examples relate to the situation in the social context istodobno nisu i »globalni«, vrlo je plastično izrazio Sari Hanafi, izvanredni profesor na Američkom sveučilištu u Beirutu, koji se u naslovu svojih nedavnih predavanja i publikacija (Hanafi, 2010, 2011) poigrao poznatom krilaticom »objavi ili nestani« (publish or perish).

Prema Hanafiju, situacija znanstvenika/ca u geografskom području koje naziva »arapskim Istokom« (obuhvaća Egipat, Siriju, Palestinske teritorije, Jordan i Libanon) može se izraziti izravnom suprotstavljenošću dviju mogućnosti: »objavi globalno i nestani lokalno«, ili pak »objavi lokalno i nestani globalno«.

Primjenjivost te dvojbe na stanje u drugim zemljama u sličnom položaju ne zaustavlja se, međutim, tek na eventualnom osobnom izboru znanstvenika/ca koji imaju priliku međunarodno objavljivati. Riječ je, kao što otkrivaju Hanafijeva razmatranja, o procesu koji ustrajavanjem na institucionalnom izomorfizmu s »globalnim igračima« (u njegovim primjerima, američkima), može duboko dekapacitirati lokalnu znanost za nošenje s problemima koje mora razriješiti lokalna zajednica.

Hanafi (2010: 5), primjerice, tvrdi da se zamisao efektivno proklamirane »jednostavne internacionalizacije« oslanja na modernistički imperativ proizvodnje »objektivnog« znanja: takav pristup zapostavlja situirana pitanja (»za koga, za što, za kada, za gdje« i »s čijeg motrišta«), sukladno tome privilegira teorijsku i statističku analizu te dovodi do povlačenja sa scene terenskog rada i tekstualne analize.

Hanafijevi primjeri odnose se, dakako, na situaciju u sredini u kojoj dje- 
he is active in. In addition to what he describes in his lectures and texts, there exists a whole range of other mechanisms of exclusion of certain topics and approaches from international journal production: all of them should be contextualized and discussed in detail.

Namely, should we not understand their causes and consequences, the strategies devised to overcome these hurdles can lead researchers to act in tune with the priorities set before them by others, in order to be published and to be quoted. This is especially true for young researchers, seeking recognition in an increasingly competitive context. In such a situation, it is easy to betray the demands of one's own academic specialization. The same goes for some burning needs of the society in which one is active as a researcher, and which in the end - in this part of the world - still predominantly funds research activities through various public funding bodies.

How to exit in this situation, or which is probably a more appropriate question in the case of Croatian sociology - how not to fall into it? Although this has not been the case so far, at least not to a large extent, there is little doubt that the announced changes in the system of funding research and in the rules of career advancement will require an increased international presence, especially of the young researchers.

As I have already said, in principle I agree with the measures Štulhofer, Baćak and Šuljok propose in order to increase international productivity and visibility of Croatian sociology. However, I do not believe that this is all that needs to be done in order to bridge the gap between the components of the alternative between "publishing globally and perishing locally" or "publishing locally and perishing globally". luje. Postoji još cijeli niz mehanizama isključivanja pojedinih tema i pristupa iz međunarodne časopisne produkcije: sve bi ih valjalo podrobno razmotriti i kontekstualizirati.

Naime, ne bude li se dobro razumjelo njihove uzroke i posljedice, izbjegavanje takvih prepreka može navesti znanstvenike/ce - osobito mlade, željne afirmacije u kompetitivnom okruženju - na istraživanja u skladu s prioritetima mogućnosti objave i postizanja citatnog odjeka. U takvoj situaciji lako je iznevjeriti zahtjeve vlastite akademske specijalizacije ili goruće potrebe društva u kojem se kao znanstvenik/ca djeluje, a koje - u krajnjoj liniji - u ovim krajevima još uvijek najvećim dijelom financira svačije djelovanje u znanosti.

Kako izići iz ovakve situacije, ili - što je u slučaju hrvatske sociologije vjerojatno primjerenije pitanje - kako ne zapasti u nju? Iako se to dosad nije događalo u većoj mjeri, nema sumnje da će najavljene promjene u sustavu financiranja znanosti i znanstvenog napredovanja i u Hrvatskoj, napose od mladih istraživača/ica, zahtijevati veću međunarodnu nazočnost.

Kao što sam rekao već na početku ovog teksta, u osnovi se slažem s mjerama koje u svrhu veće međunarodne produktivnosti i vidljivosti hrvatske sociologije preporučuju Štulhofer, Baćak i Šuljok. Međutim, ne mislim da je to sve što je potrebno učiniti da bi se "premostio« jaz između sastavnica alternative »globalnog objavljivanja i lokalnog nestajanja« ili »lokalnog objavljivanja i globalnog nestajanja $\ll$.

Uz poticanje objavljivanja u međunarodnim časopisima (osobito $\mathrm{u}$ onim slučajevima u kojima takvi pokušaji ne pretpostavljaju drastično iznevjeravanje 
In addition to rewarding publishing in international journals (especially in the cases where such attempts do not entail a drastic betrayal of one's research mission or of the needs of the local community), I argue in favour of hard work needed to increase the quality of the reviewing process and the general quality of articles published in Croatian sociological journals.

At the recently held National Congress of the Croatian Sociological Association (CSA), Professor Štulhofer expressed his scepticism regarding the possibility of achieving in the "local" journals the quality of the reviewing process matching that of the more influential international publications. In contrast with his view, I do not see such an activity as "mission impossible". Likewise, I believe that the new editorial policy of the Revija za sociologiju has made decisive steps in the right direction. What is more, I actually see a better international future for Croatian sociology only if "internationalization" also happens in situ, in other words if it is not based simply on the continual need to meet the criteria set elsewhere.

This is how I understood the statement made in the presidential address of the former CSA's president Inga TomićKoludrović, quoted at the beginning of the Štulhofer, Baćak and Šuljok Forum contribution (2010: 103). In TomićKoludrović's view, Croatian sociology will not be able to fulfil its public role unless it becomes international, measuring "itself in professional terms on the basis of global criteria" (TomićKoludrović, 2009: 174/175).

I interpret this in the following way: when researching what is of importance "here and now", sociologists in Croatia need to be competent in the same way as vlastite istraživačke misije i/ili potreba lokalne zajednice), zalažem se za mukotrpan rad na podizanju kvalitete recenzijskog postupka i opće kvalitete priloga u hrvatskim sociološkim časopisima.

Kolega Štulhofer na nedavnom je Nacionalnom kongresu Hrvatskoga sociološkog društva (HSD) izrazio svoju skepsu u pogledu mogućnosti da »domaći« časopisi postignu kvalitetu recenzijskog postupka jednaku onoj koja se dobiva $u$ međunarodno referiranim publikacijama znatnijeg utjecaja. Meni se, pak, djelatnost na takvom projektu ne čini »nemogućom misijom«, a smatram također da je nova urednička politika Revije za sociologiju učinila odlučne korake u tom smjeru. Štoviše, bolju međunarodnu budućnost hrvatske sociologije vidim zapravo samo ako se »internacionalizacija« dogodi i in situ, a ne tek na temelju potrebe stalnog zadovoljavanja drugdje postavljanih kriterija.

Upravo sam u tom smislu shvatio tvrdnju iz predsjedničkog govora bivše predsjednice HSD-a Inge Tomić-Koludrović, koju na početku svog priloga u Forumu navode Štulhofer, Baćak i Šuljok (2010: 103), a prema kojoj hrvatska sociologija neće moći ispuniti svoju javnu ulogu ako ne postane međunarodna, odmjeravajući sebe, u profesionalnom smislu, na temelju globalnih kriterija (Tomić-Koludrović, 2009: 174/175).

Drugim riječima, čini mi se da u istraživanju onoga što je važno »ovdje i sada« sociolozi/ginje u Hrvatskoj moraju biti kompetentni na način na koji je to potrebno da bi se članci objavili $\mathrm{u}$ međunarodnim publikacijama. Isto tako, smatram da bi bilo poželjno i da 
is necessary in order to publish in international publications. At the same time, I believe it would be desirable to publish as many as possible of the competently written texts from other sociological communities in the "local" Croatian journals. Perhaps this vision is too optimistic, but I thought it necessary to propose it as a possible "horizon of expectations".

In the end, I would like to express my gratitude to the authors of the Forum contribution that served as an inspiration for this text. I urge all other readers of the Revija za sociologiju to join the discussion on whether we need - as Ignac Lovrek (2010) asked in a noted presentation - "research with impact - scientific, economic, social", or "research with impact factor"? Or just "research"? Any of the three possible answers to this question will have an effect on journal production, and that production itself paves the way to the desired profile of research activity. For this reason, I believe it is necessary to discuss acceptance criteria for journal publication more so now than has been the case even in the recent past.

\section{LITERATURA / REFERENCES}

AR (2010). »JCR Rankings: Reports on Impact Factor for the Year 2009«, Annual Reviews, http://www.annualreviews.org/page/about/isi-rankings (15. 04. 2011).

CMJ (2010). »News 18. 06. 2010 New Impact Factor«, Croatian Medical Journal, http://www.cmj. $\mathrm{hr} /$ ?show $=16767$ (15. 04. 2011)

Fleck, Christian (2010). »Diversity or Fragmentation in Europe's Sociology: Lessons to be Learned?«, in: Michael Burawoy, Mau-kuei Chang \& Michelle Fei-yu Hsieh (eds). Fa- se što više dobrih tekstova iz drugih socioloških sredina objavi u »domaćim« hrvatskim časopisima. Možda je ova vizija preoptimistična, no činilo mi se da ju je bilo potrebno postaviti kao mogući »obzor očekivanja«.

Autorima $\mathrm{i}$ autorici priloga u Forumu koji je potaknuo ova razmišljanja želio bih na tome izraziti zahvalnost. Sve druge čitatelje/ice Revije za sociologiju pozivam da se uključe u raspravu o tome jesu li nam - kako je to u jednom svom zapaženom istupu zapitao Ignac Lovrek (2010) - potrebna »znanstvena istraživanja $\mathrm{s}$ utjecajem - znanstvenim, ekonomskim, društvenim«, »znanstvena istraživanja s čimbenikom utjecaja«, ili pak samo »znanstvena istraživanja«? Bilo koji od triju mogućih odgovora na ovo pitanje imat će, naime, odjeka u časopisnoj produkciji, a ona istodobno nužno stvara pretpostavke za stvaranje željenog profila znanstvene djelatnosti. Stoga se, smatram, danas više nego ikad u recentnoj prošlosti potrebno baviti časopisima i raspravljati o kriterijima objavljivanja.

cing an Unequal World: Challenges for a Global Sociology (Volume 3: Europe and Concluding Reflections). Taipei: Institute of Sociology, Academia Sinica, Council of National Associations of the International Sociological Association, 3-22, http://www.ios.sinica.edu.tw/cna/ download/proceedings/38.Fleck.Austria.pdf (15. 04. 2011).

Hanafi, Sari (2010). »Publish Globally and Perish Locally: Rating System in the Elite Universities in the Arab East«, ASA Footnotes, 38 (5): 5-6, http://www.asanet.org/footnotes/ 
mayjun10/images_new/MayJun10 Footnotes.pdf (15. 04. 2011).

Hanafi, Sari (2011). »University Systems in the Arab East: Publish Globally and Perish Locally vs Publish Locally and Perish Globally«, Current Sociology, 59 (3): 291-309. doi:10.1177/0011392111400782

HEFCE (2010). »Bibliometric pilot exercise 2009«, Higher Education Funding Council for England, http://www.hefce.ac.uk/research/ref/ develop/ (15. 04. 2011).

Jacobs, Jerry A. (2010). »Journal Rankings in Sociology: Using the $\mathrm{H}$ Index with Google Scholar«, https:// sociology.sas.upenn.edu/sites/sociology.sas.upenn.edu/files/Journal $\% 20$ Rankings\%20in\%20Sociology $\% 20$ jacobs $\% 20$ august $\% 202010$. doc $\% 20$ -101 (15. 04. 2011).
Lovrek, Ignac (2010). »Doktorska škola«, Konferencija Reforma visokog obrazovanja: inventura 2010., Varaždin (FOI), 9-10. travnja 2010., [ppt], http://doktorski.unizg.hr/dokt?@= 5tfo (15. 04. 2011).

Štulhofer, Aleksandar, Baćak, Valerio \& Šuljok, Adrijana (2010). »Provincijalni karakter hrvatske sociologije? / A Parochial Status of Croatian Sociology?«, Revija za sociologiju, 40 (1): 103-108.

Tomić-Koludrović, Inga (2009). »Pogled u budućnost: sociologija kao multiparadigmatska, refleksivna i javna znanost / A View of the Future: Sociology as a Multiparadigmatic, Reflexive and Public Science $\ll$, Revija za sociologiju, 40[39] (3-4): 139-181. 